\title{
Téoros
}

Revue de recherche en tourisme

\section{Ranking Tourism Attractions According to their Suitability for Public Investment in Gansu Province, China}

Nick Novakowski, Rémy Tremblay et Edward Leman

Volume 27, numéro 1, printemps 2008

URI : https://id.erudit.org/iderudit/1070898ar

DOI : https://doi.org/10.7202/1070898ar

Aller au sommaire du numéro

Éditeur(s)

Université du Québec à Montréal

ISSN

0712-8657 (imprimé)

1923-2705 (numérique)

Découvrir la revue

Citer cet article

Novakowski, N., Tremblay, R. \& Leman, E. (2008). Ranking Tourism Attractions According to their Suitability for Public Investment in Gansu Province, China. Téoros, 27(1), 59-66. https://doi.org/10.7202/1070898ar d'utilisation que vous pouvez consulter en ligne. 


\section{Ranking Tourism Attractions According to their Suitability for Public Investment in Gansu Province, China}

\section{Nick Novakowski, Rémy Tremblay and Edward Leman}

\section{Introduction}

While assessments of tourism attractions are among the fundamentals of tourism planning, they are the "poor cousins" of accessibility, transportation, and accommodations analysis (Pearce, 1991). Ranking tourism attractions in China is fraught with complexity because of the market's tremendous growth and idiosyncratic character. The entire country as a tourism landscape is only now opening itself up to external review and the open doors are revealing the profound depth of the experiences that are available.

Tourism to and within China slowed dramatically in 2003, both during and after the SARS (severe acute respiratory syndrome) outbreak. However, there has been a strong rebound and China, by displacing Italy, is now the world's fourth top tourist destination following France, Spain, and the United States (WTO, 2006). Hong Kong, measured on its own by the World Tourism Organization, is now ranked tenth in the world as a travel destination (WTO, 2005). In fact, tourism in Asia is growing faster than anywhere else in the world (WTO, 2007). Currently, tourism constitutes $6.1 \%$ of China's GDP (gross domestic product) and the industry is expected to grow at least 10\% for each of the next five years. By 2020, it is anticipated that China will be the world's largest tourism market (Jie, 2007). At this time, however, it is unclear whether such tourism growth will continue to favour coastal China in the same way that foreign investment has.
The coastal/interior dichotomy of China is ongoing. The interior of China continues to be fraught with a menu of problems that confound economic and touristic development: geographic isolation, poor management, ethnic conflict, economic inefficiency, and ecological degradation (Wei and Fang, 2006). Consequently, the Chinese government, under the aegis of the Western Development Strategy, has been launching an enormous effort to redirect development away from the coast and into the less prosperous interior. Because tourism is being touted by the central government as an economic pillar, tourism growth represents one way in which to attempt to develop the country's interior regions. At the same time, the interior of China has an enormous endowment of heritage resources.
This means that sustainable tourism in China will depend, to some degree, on how well the country can protect its heritage assets. Concerns about whether heritage assets will be neglected, destroyed, redeveloped, overused, or overcommercialized are all valid concerns regarding sustainability. In this paper, we look at a variety of tourist attractions in Gansu Province. Surprisingly, "only limited research attention has been paid specifically to tourist attractions, although they occupy a vital position in tourism development" (Hu and Wall, 2005: 617-618). We then demonstrate a range of evaluation criteria that can be employed to explore the tenability of using public money to further develop these attractions.

\section{Figure 1}

Gansu Province and the Project Sites Under Investigation

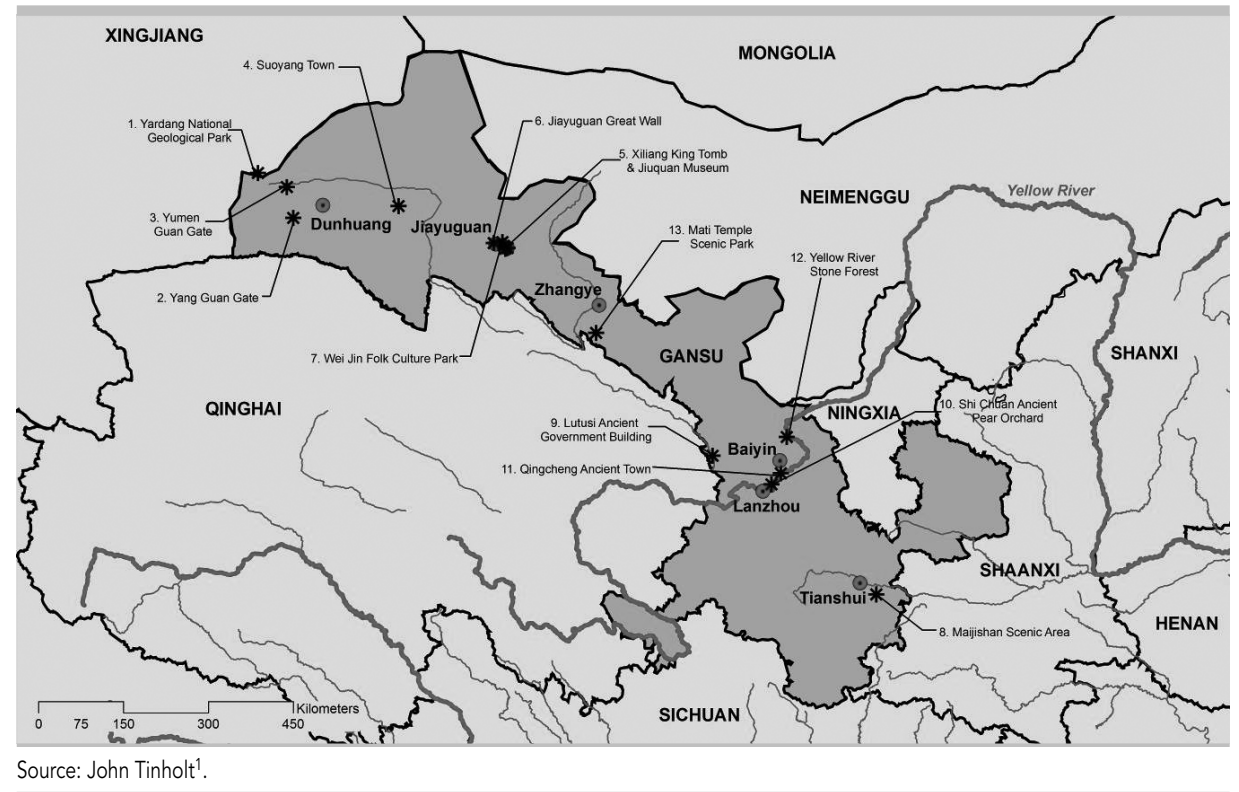




\section{Gansu Province}

Gansu Province is located in northwestern China. The province lies between the Gobi Desert of Inner Mongolia (Neimenggu) to the north and the Qilian Mountains ringing the Tibetan plateau to the south. It was an important segment of the overland route of the ancient Silk Road before marine transport came to dominate global commerce. The historical Silk Road had two routes (north and south) that converged at Dunhuang, where the routes are then funnelled through the Hexi Corridor, to Lanzhou and later to Tianshui, and end at Xi'an (formerly Chang'an) in neighbouring Shaanxi Province. The Hexi Corridor is the narrow neck demonstrated in the middle of the province. Of China's 31 provinces, Gansu Province is ranked second poorest according to per capita income, ahead of only Guizhou Province (Wagstaff and Yu, 2007).

\section{The Setting of Gansu Province}

The physical setting of Gansu Province is important to tourism analysis because the great variety of evident landscape types imposes significant limitations on the sort of tourism that can be sustainably supported. The dramatic variety of landscapes arises from the intersection of three plateaus - the Loess, the Tibetan, and the MongolianXinjiang. The province's topography ranges from the flat Gobi Desert plains in the northwest, to loess landscapes in the middle of the province, to aggressively hilly terrain in the southeast. Rainfall levels steadily increase as one moves from the desert, in the northwest and centre, to the southeast (which is a forest-covered subtropical zone that is the location of one of the northernmost refuges for the giant panda). Overall, grasslands cover $35.4 \%$ of the province; the Gobi and other desert components cover $26 \%$, forests $8.7 \%$, and croplands $12.9 \%$, with mountains, urban areas, and non-productive uses making up the remainder (Zhenggang et al., 2003). Along the Hexi Corridor, the most habitable areas follow a sequence of oases that flourish at the expense of overusing slowly recharged groundwater. Once the Hexi Corridor reaches the Lanzhou area, the loess soils and the water resources from the Yellow and other year-round rivers improve habitability in the eastern portion of the province.

\section{The Project Sites}

In this project undertaken for the Gansu provincial government, thirteen different sites (listed in table 1) throughout the province were visited and analyzed. A ranking framework to assess the priorities for public investment was generated and implemented.

All 13 sites are grouped around core cities within the province that can be accessed either by plane, train, or road. The five core cities are: Dunhuang, Lanzhou, Zhangye, Jiayuguan, and Tianshui. While Lanzhou is the dominant urban centre and also the provincial capital, its ability to serve the regions and urban centres in the province's northwest region, such as Dunhuang and Jiayuguan, is constrained. In addition, the far southeast regions of the province centred on Tianshui are just as close to Xi'an (the capital of Shaanxi Province) as to Lanzhou, and consequently have strong economic, social, tourism, and related linkages with the Shaanxi capital.

In the Dunhuang area, the proposed projects are scattered across a desert plain. The sites are only partially clustered. The Yang Gate project involves the ruins of the southern pass of the Silk Road. The Yumen Gate (Jade Gate) project involves the northern pass of the Silk Road approximately 90 kilometres northwest of Dunhuang. The Yardang Geological Park project involves a geological formation of rock ridges caused primarily by wind erosion. Meanwhile, the Suoyang Town project is an ancient city and desolate castle. The castle was partially destroyed in 1521, but many relics and remnants survived. During a site visit in July 2005, shards of Ming pottery still littered the interior of the castle.

Like the Dunhuang attractions, the Jiayuguan area is also being encroached upon by the Gobi Desert. In that area, all of the project sites are concentrated around the two major urban areas: Jiayuguan and Jiuquan. The Xiliang King Tomb and the Jiuquan Museum projects focus on muraldecorated tombs. The Jiayuguan Great Wall project (which includes three sites: the Fortress, the First Signal Tower, and the Overhanging Wall) is already a UNESCO (United Nations Educational Scientific and Cultural Organization) World Heritage Site. The Fortress component of the project is also known as the Jiayuguan Pass. The Overhanging Great Wall is the western end
Table 1

The Thirteen Sites Analyzed

\begin{tabular}{l|l}
\hline Site Analyzed & $\begin{array}{c}\text { Type of } \\
\text { Tourism } \\
\text { Attraction }\end{array}$ \\
\hline 1 Yardang National Geological Park & Natural \\
2 Yang Gate & Cultural \\
3 Yumen Gate & Cultural \\
4 Suoyang Town & Cultural \\
5 Xiliang King Tomb / Jinquan Museum & Cultural \\
6 Jiayuguan Great Wall & Cultural \\
7 Wei Jin Folk Culture Park & Cultural \\
8 Maijishan Scenic Area & Cultural \\
9 Lutusi Ancient Government Buildings & Cultural \\
10 Shi Chuan Ancient Pear Orchard & Cultural \\
11 Qingcheng Ancient Town & Cultural \\
12 Yellow River Stone Forest & Natural \\
13 Mati Temple Scenic Park & Cultural \\
\hline
\end{tabular}

Source: Authors.

of the Ming Wall. The Wei Jin Folk Culture Park is similar in theme to the tombs of Dingjiazha. The site contains over 1400 tombs built during the Wei and Jin Dynasties (220-420 CE).

There is only one site in the Zhangye area: the Mati Temple Scenic Park (directly south of Zhangye). It is a Buddhist cave complex etched into the side of a cliff in the Sunan Yugu (Tibetan) Autonomous Prefecture. The Lutusi Ancient Government Buildings are a governance complex known as The Small Imperial Palace. Near Lanzhou, the Shi Chuan Ancient Pear Orchard grows nationally renowned pears, many of which come from trees that are 300 years of age and older. The Qingcheng Ancient Town (a mercantile town with architecturally-significant courtyard houses) is nearby. The Yellow River Stone Forest is located north of Lanzhou and is a geological park known for its unique stone formations (referred to as trees). Moving southeast, the Tianshui area involves the Maijishan Scenic Area, an ancient series of Buddhist grottoes with high potential tourist volume due to its proximity to both Xi'an and a planned airport conversion from military to civilian uses. 


\section{The Framework for Ranking the Suitability of Tourism Sites for Public Investment}

\section{The Theoretical Approach}

Planning is important to tourism development for a wide range of reasons. First, through the capacity of physical processes to control development, it provides a mechanism for a structured provision of tourist facilities and associated infrastructure over large geographic areas. As the spatial range of tourists has become more extensive with the increase in mobility levels, planning systems that are capable of coordinating development over regional and even national spaces have become more necessary (Gunn, 1988). Second, in view of the natural patterns of fragmentation within tourism, any system that permits coordination of activity is likely to become essential to the development of the industry's potential. That fragmentation is mirrored in the many different elements that are required to come together within a tourism plan (Murphy, 1985). Third, there are clear linkages between planning and principles of sustainability. Implicit in the concept of sustainable tourism are a range of interventions aimed not only at conserving resources upon which the industry depends, but also at maximizing the benefits to local populations that may accrue through proper management of those resources. The most common form of intervention is via a tourism plan (Pearce, 1989). The tourism plan, by definition, must focus on a limited number of tourism attractions that compete for limited public funding. Fourth, planning can be a mechanism for the distribution and redistribution of tourism-related investment and economic benefits. That is a particularly important role for planning, given that tourism is not only an industry of global significance, but one where activity does not fall evenly across different regions (Baum, 1994). China, perhaps more than most countries, exemplifies such "have and have not unevenness" (stated differently, coastal regions versus the interior).

\section{The Methodology}

The methodology presented here was used to generate a ranking of the suitability for public investment of 13 individual attractions in Gansu Province. The approach is to: 1) make the evaluation criteria and their use transparent; and 2) provide the means for discussion among the Chinese decision makers.
The ranking process is executed in three stages, with a matrix (or table) associated with each stage. In the first stage, an inventory of all of the data sources uncovered in a systematic literature review on the thirteen sites is generated. The research result is a data matrix where all of the data sources are itemized. For this paper, this would include data from 2004 for which some key provincial and sub-provincial (county, city scale) statistical figures are available, as well as data from the 2000 Census (the latest year for which the National Census was taken at the time of the research and that, for the first time, enumerated migrants resident in a city for longer than six months were included). Other data sources include: maps generated using geographic information systems (GIS), yearly Statistical Handbooks for both China and Gansu Province, and field observations.

In the next stage of the research process, a second matrix that captures a calculation of thematic values is generated where the different project sites are ranked according to five themes: marketability, economic spillovers, human capital, local government capability, and environmental sustainability. These themes are representative of a framework suitable for being employed by a government client. If a private company or a corporation were undertaking the assessment, different themes would likely be selected. Each theme (or master criterion) has 100 available points that are divided evenly among the descriptive sub-criteria. Then, each site is rated as to how well it meets a particular criterion; that rating $(R)$ is assigned on a scale from 0 to 1 according to expert opinion. Each rank is then multiplied by the weighting $(\mathrm{W})$ for that criterion to get a weighted value $\mathrm{V}$ (i.e., $\mathrm{V}=\mathrm{R} \times \mathrm{W}$ ). For example, if the weight is $25 \%$, then the rating is multiplied by 25 . The sub-totals of these values are added up for each theme in order to provide a "theme value."

The third stage of the research process involves a presentation of the overall evaluation results combined with a weighting. In the previous research stage, the results were generated whereby each theme value had equal weight. In the third stage, the themes are weighted according to their ability or capacity to change (although the government or another client may prefer a different rationale). In this ranking exercise, the weighting scheme employed reflects the following rationale: the marketability, economic spillo-

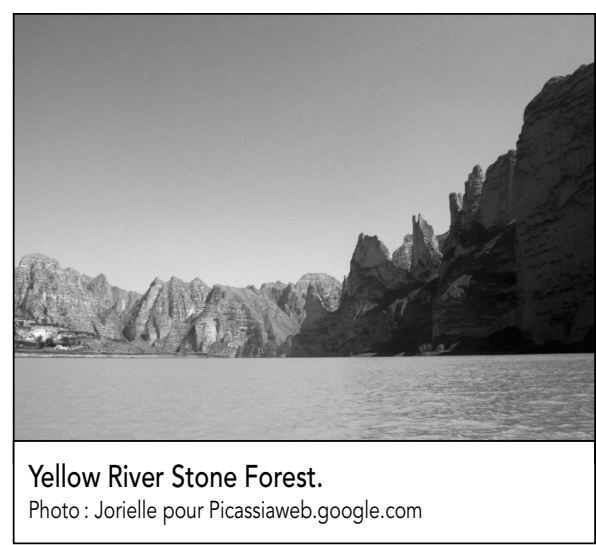

vers, and environmental sustainability themes are more resistant to change for the better in the short run (particularly environmental sustainability). At the same time, educational inputs can change the capabilities and capacities of human capital and local government in as little as a few years. Therefore, because human capital and local government are less resistant to change for the better through market and government forces, they are weighted as less important. This capacity to change weighting reflects both geography and historical development inertia. To complete the third stage, theme values are divided by 100, and inserted into the "rating" cells for each master criterion. Then, the rating cells are multiplied by their weights, giving a final value, or FV. After the final values are totalled for each site, the best candidates among those available for site development according to these evaluation criteria are revealed.

\section{Explanation of Evaluation Criteria and Measures}

The first master criterion — marketability - is based on four elements: multi-modal accessibility to the portal city by tourists; accessibility to the project site from portal cities; heritage attractiveness; and amenability to circuit programming. With the sub-criterion of multi-modal accessibility to the portal city, the concern is how easily tourists both within and from outside the province can access the portal city closest to the tourism site. The more linkages by different transportation modes (air, road, rail) there are, the better.

Meanwhile, accessibility to project sites from portal cities is important in a number of ways. For example, the desire to see a site is related to the ease of getting to that site from the portal city (the city where the 
tourist is most likely to stay in a particular area). If the drive time to the site from the portal city is long, then there is a disincentive to visit it. The input value is the number of hours that it takes to get from the portal city to the site by roadway. Sites that are within the portal city or within one hour of it get a value of 1 (the maximum). Other sites are calculated according to drive time. For example, if the site is 2 hours away it gets a value of 0.75 , if 3 hours away a value of 0.5 . Sites more than 4 hours away are assumed to involve an overnight stay and get a value of 0 .

Heritage attractiveness addresses the heritage value of each site. In our case, the heritage attractiveness values are taken from experts. The heritage attractiveness score is a function of actual heritage content, commitment to appropriate use (including protection, research and education), separation of heritage (actual or planned) from recreation and amusement, and dual content (both heritage and natural content). The Maijishan Scenic Area receives the highest heritage value and is given a rank of 1 . The ranks for the other sites are calculated by proportion accordingly.

Amenability for circuit programming can focus on either of two types of circuits: thematic or spatial. All of the cultural heritage sites in the inventory can be linked thematically through the Silk Road. Therefore, we chose to focus on spatial circuitry where each site is assessed for being in spatial proximity to other sites that can be combined on one visit. Any combination of sites in proximity can increase capture time. A site on its own with no connectivity to other project sites within the same day gets a 0 , whereas a site in proximity to other project sites, nationally protected cultural sites, or International Union for the Conservation of Nature (IUCN) protected areas gets a positive value.

The second master criterion of economic spillovers addresses the extent to which development of the tourism attraction is capable of contributing to the local economy. Throughout the world, this is an important function of tourism development. Using available Chinese data, there are four variables addressed as proxies for economic spillover: size of the local labour market; accessibility to local enterprises; ability to attract new investment via per capita GNP (gross national product); and ability to attract new investment
Table 2

The Elements of Marketability

\begin{tabular}{|c|c|c|}
\hline Evaluation Criterion & Measure & Input Value to Matrix \\
\hline \multirow[t]{14}{*}{ Marketability } & Multi-modal accessibility & $\begin{array}{l}\text { Presence of an airport, NTHS (National Trunk } \\
\text { Highway System), and rail is given a value of } 1\end{array}$ \\
\hline & & Presence of two of three (airport, NTHS, rail): 0.67 \\
\hline & & Presence of one of three (airport, NTHS, rail): 0.33 \\
\hline & & Lack of airport, NTHS, and rail: 0 \\
\hline & Accessibility from portal cities & Within a 1-hour drive: 1 \\
\hline & & Within a 2-hour drive: 0.75 \\
\hline & & Within a 3-hour drive: 0.5 \\
\hline & & Within a 4-hour drive: 0.25 \\
\hline & & Greater than a 4-hour drive: 0 \\
\hline & Heritage attractiveness & Driven by expert consensus. Values from 0 to 1 \\
\hline & Amenability for & High: spatial proximity to 3 or more other sites: 1 \\
\hline & circuit programming & Medium: spatial proximity to 2 other sites: 0.67 \\
\hline & & Low: spatial proximity to 1 other site: 0.33 \\
\hline & & No connectivity (no other nearby sites): 0 \\
\hline
\end{tabular}

Source: Authors.

via local savings rates. The size of the local labour market is determined by people between 15-65 years of age (using the 2000 Census) living within one-hour's drive time of the site. The ranking is done on the basis of proportions. With accessibility to local enterprises, that variable addresses the enterprise concentration in the area (i.e., the tertiary economy), and it reveals whether there are local services in the area that serve some of the needs of tourists for food, accommodation, transportation, entertainment, education, and occasional requirements (haircutting, laundry, etc.). Quantiles are used. With the ability to attract new investment, GNP per capita is used as a proxy to reflect the following in China: levels of urbanization, levels of retail sales, previous saving, past investment activity, and future investment opportunities. The Jiayuguan Cluster has the highest GNP per capita and gets a value of 1 . The other regions are presented based upon a proportional calculation. The data are derived from the 2004 Statistical Yearbook for Gansu Province. Finally, with the ability to attract new investment, local available savings are used as a function of disposable local incomes. As well, they provide an indication of future available monies that can be used to start up local enterprises that may service tourists. The local savings rate is multiplied by the GNP per capita and the data are extracted from the 2004 Statistical Yearbook.

Human capital is the third of the five master criteria and recognizes that, in order for tourism to generate local economic development opportunities, the resident community requires increasingly higher levels of human resource capital, since tourism is no longer simply about the feeding, housing, and transportation of tourists. The development of human capital is important to ensure that tourists are provided with a high quality learning and entertainment experience when they are being fully serviced by local entrepreneurs and workers. Human capital in that context can be regarded as a function of the following factors: literacy, educational attainment, ethnic population, and female literacy. In China, dialects are common and an understanding of different patterns of speech improves the ability of tourism interpreters to deliver a higher quality experience.

Literacy is important because some tourism information is printed and represents part of the information culture. In addition, the use of computers requires literacy. Literacy in this evaluation process is assessed and inputted into the matrix as 1 minus the illiteracy rate. 


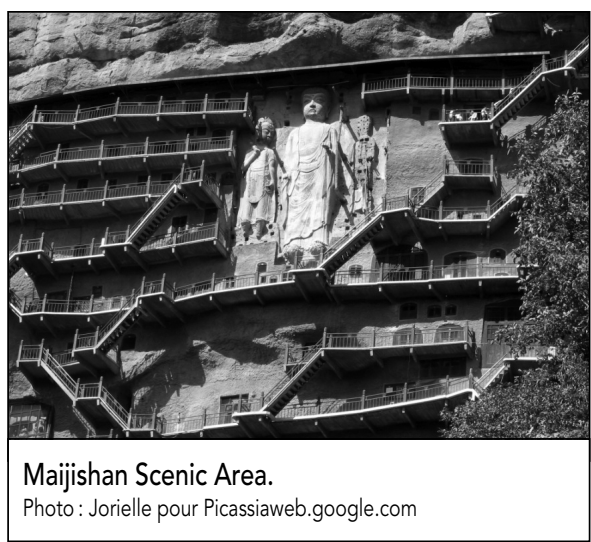

Therefore, the more illiterate people there are in the area, the lower the assessed value for that area. Dunhuang has the highest literacy proportion. Meanwhile, educational attainment or years of education is used to reflect the overall educational levels of the region's population. For that variable, the region with the highest educational levels is also Dunhuang, which reflects the correlation between educational attainment and literacy.

In China, there are 55 officially recognized ethnic minorities outside of the Han majority. Because many of the ethnic groups inhabit the non-coastal interior regions of the country, they have been targeted for additional economic aid and relaxation of the one-child policy. Ethnic population as a percentage of a county population can be used as a proxy for lower-income levels in some Chinese provinces (i.e., among the poorest segments of Gansu's population are its minorities). The data analyzed are derived from the 2000 census and weighted on a proportional basis, with the region having the largest percentage of ethnic minorities being assigned a value of 1 . With ethnic population receiving priority attention, it makes tourism projects in their areas also a priority. The gender characteristics of the local labour market are also relevant. Women are the dominant employee sector in the tourism industry in China. That partly reflects the predominance of women in the tertiary sector and that measure is a proxy for the existing capacity of women within the resident community to effectively fill the positions that arise from the development of tourism attractions.

The fourth master criterion involves local government capabilities, which reflect how well the local government will be able to support and facilitate tourism spending, gover- nance, and implementation. There are three variables used to capture local government capabilities: per capita on-budget revenues and expenditures; per capita retail sales; and fixed asset investment per capita. Per capita on-budget revenues and expenditures are used to capture the capacity to provide services and investment. The data are derived from the 2004 Statistical Yearbook and weights are allocated on a proportional basis with the government, the strongest balance sheet receiving a ranking of 1 . Meanwhile, per capita retail sales are used as a proxy for the VAT (value-added tax). The higher the amount of retail sales, the greater the tax revenues will be for local government. The data are derived from the Statistical Yearbook and weights are allocated on a proportional basis with the government, the strongest balance sheet receiving a ranking of 1 . Fixed asset investment can be used as a measure of the investment capacity of local governments. That variable provides an indication of the potential ability of resident governments to fund ancillary investments to support the development of the tourism sector. The data are derived from the 2004 Statistical Yearbook and weights are allocated on a proportional basis with the government, the strongest balance sheet receiving a ranking of 1 .

Environmental sustainability is the fifth master criterion and addresses priority environmental issues for Gansu Province. Two issues - the extent of vulnerable land uses within a region and water availability within a region-are employed as proxies to provide insight into whether an attraction can sustain mass tourism over time in a largely water-deprived province. For addressing the extent of vulnerable land uses, polygon measurement with GIS is used to calculate the vulnerability of the region (vulnerable landscapes are defined as those landscapes that are easily disturbed and slow to recover, or those that can easily degrade into less complex ecosystems). Good examples of vulnerable landscapes within an arid context like Gansu Province include steppe, alpine and sub-alpine grasslands, arid grasslands, and desert. Total land use for a region is given a value of 1 . From that value, all vulnerable land uses are calculated as a percentage and subtracted from 1. If $30 \%$ of the defined tourism area is vulnerable land, then the cluster gets a value of $1-0.3=0.7$.
Therefore, regions with larger areas of vulnerable terrain get lower values.

Water availability in Gansu Province is driven by two factors: available surface water and rainfall. Gansu Province can be mapped into three precipitation regimes of high, medium, and low. The values are provided below. Site visits and/or literature reviews are used to confirm whether desert sites are overexploiting ground water that could not be sustained in the long term. Adjacency of the project site to a year-round river is assigned a value of 1 .

High: sites in regions with high annual precipitation $(500-1000 \mathrm{~mm})=1$.

Medium: sites in regions with medium annual precipitation $(100-499 \mathrm{~mm})=0.67$.

Low: sites in regions with low annual precipitation $(0-99 \mathrm{~mm})=0.33$.

No water: desert sites with limited infrastructure for extracting groundwater to support a daily influx of tourists $=0$.

\section{Research Results}

Only regions with vastly different population profiles, water endowments, extent of vulnerable ecosystems, economic development, etc. are presented in the research results. The matrices capturing all of the sites are too large for this publication and two different locations are sufficient to demonstrate how the matrices work (the two selected locations are Dunhuang and Lanzhou). As stated, the research methodology has been divided into three stages and a matrix will be the research result of each stage. The first research result is the data source matrix (and can be referred to as Matrix 1 for convenience). The data source matrix is individual to each research context and details the identity, provenance, and location of data sources arising from the literature review. The second stage of the methodology, meanwhile, presents the calculation of thematic values and is presented for Dunhuang and Lanzhou in Matrix 2.

Matrix 3 takes the values of Matrix 2, and weights them to reflect the ability of values to change in the short run. 


\section{Data Source Matrix}

\begin{tabular}{|c|c|}
\hline Marketability & \\
\hline - multi-modal accessibility by tourists & \multirow{4}{*}{$\begin{array}{l}\text { - Transportation Network Map generated using ArcGIS map inventory. } \\
\text { - World Bank. 2005. Gansu Cultural and Natural Heritage Protection and Development Project. } \\
\text { - Digital Elevation Model for Gansu Province generated by ArcGIS. } \\
\text { - Visual inspection of the Digital Elevation Model for Gansu Province generated by ArcGIS. }\end{array}$} \\
\hline - heritage attractiveness & \\
\hline - accessibility to portal cities & \\
\hline - amenability to circuit programming & \\
\hline \multicolumn{2}{|l|}{ Economic spillovers } \\
\hline - size of local labour market & \multirow{4}{*}{$\begin{array}{l}\text { - National Bureau of Statistics of China. 2000. Census. Beijing: China Statistics Press. } \\
\text { - National Bureau of Statistics of China. 2000. Census. Beijing: China Statistics Press. } \\
\text { - National Bureau of Statistics of China. 2004. China Statistical Yearbook. Beijing: Statistics Press. } \\
\text { - National Bureau of Statistics of China. 2004. China Statistical Yearbook. Beijing: Statistics Press. }\end{array}$} \\
\hline - accessibility to local enterprises & \\
\hline - ability to attract investment: per capita GDP & \\
\hline - ability to attract investment: local savings & \\
\hline \multicolumn{2}{|r|}{ e } \\
\hline - illiteracy rates in host county & \multirow{4}{*}{$\begin{array}{l}\text { - National Bureau of Statistics of China. 2000. Census. Beijing: China Statistics Press. } \\
\text { - National Bureau of Statistics of China. 2000. Census. Beijing: China Statistics Press. } \\
\text { - National Bureau of Statistics of China. 2000. Census. Beijing: China Statistics Press. } \\
\text { - National Bureau of Statistics of China. 2000. Census. Beijing: China Statistics Press. }\end{array}$} \\
\hline - educational attainment in host county & \\
\hline - ethnic population: \% of county population & \\
\hline - gender characteristics of labour market & \\
\hline \multicolumn{2}{|l|}{ Local government capabilities } \\
\hline - per capita on-budget revenues/expenditures & \multirow{3}{*}{$\begin{array}{l}\text { - National Bureau of Statistics of China. 2004. China Statistical Yearbook. Beijing: Statistics Press. } \\
\text { - National Bureau of Statistics of China. 2004. China Statistical Yearbook. Beijing: Statistics Press. } \\
\text { - National Bureau of Statistics of China. 2004. China Statistical Yearbook. Beijing: Statistics Press. }\end{array}$} \\
\hline - per capita retail sales & \\
\hline - fixed asset investment per capita & \\
\hline \multicolumn{2}{|l|}{ Environmental sustainability } \\
\hline - extent of vulnerable land uses & \multirow{2}{*}{$\begin{array}{l}\text { - Habitability Map for Gansu Province generated by ArcGIS. } \\
\text { - National Symposium on Population, Resources and Environment, } 2005 .\end{array}$} \\
\hline - water availability (includes desertification) & \\
\hline
\end{tabular}

\section{Calculation of Thematic Values}

\begin{tabular}{|c|c|c|c|c|c|c|c|}
\hline \multicolumn{4}{|c|}{ Dunhuang Region } & \multicolumn{4}{|c|}{ Lanzhou Region } \\
\hline 1 & 2 & 3 & 4 & 9 & 10 & 11 & 12 \\
Yardang & Yang & Yumen & Suoyang & Lutusi & Shi Chuan & Qingcheng & Yellow \\
Geological & Guan & Guan & Ancient & Ancient & Pear & Ancient & River Stone \\
Park & Gate & Gate & Town & Gov't Bldg & Orchard & Town & Forest \\
\hline
\end{tabular}

Marketability

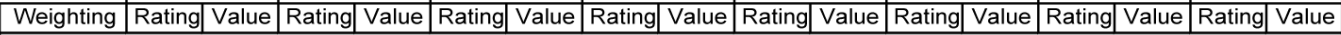

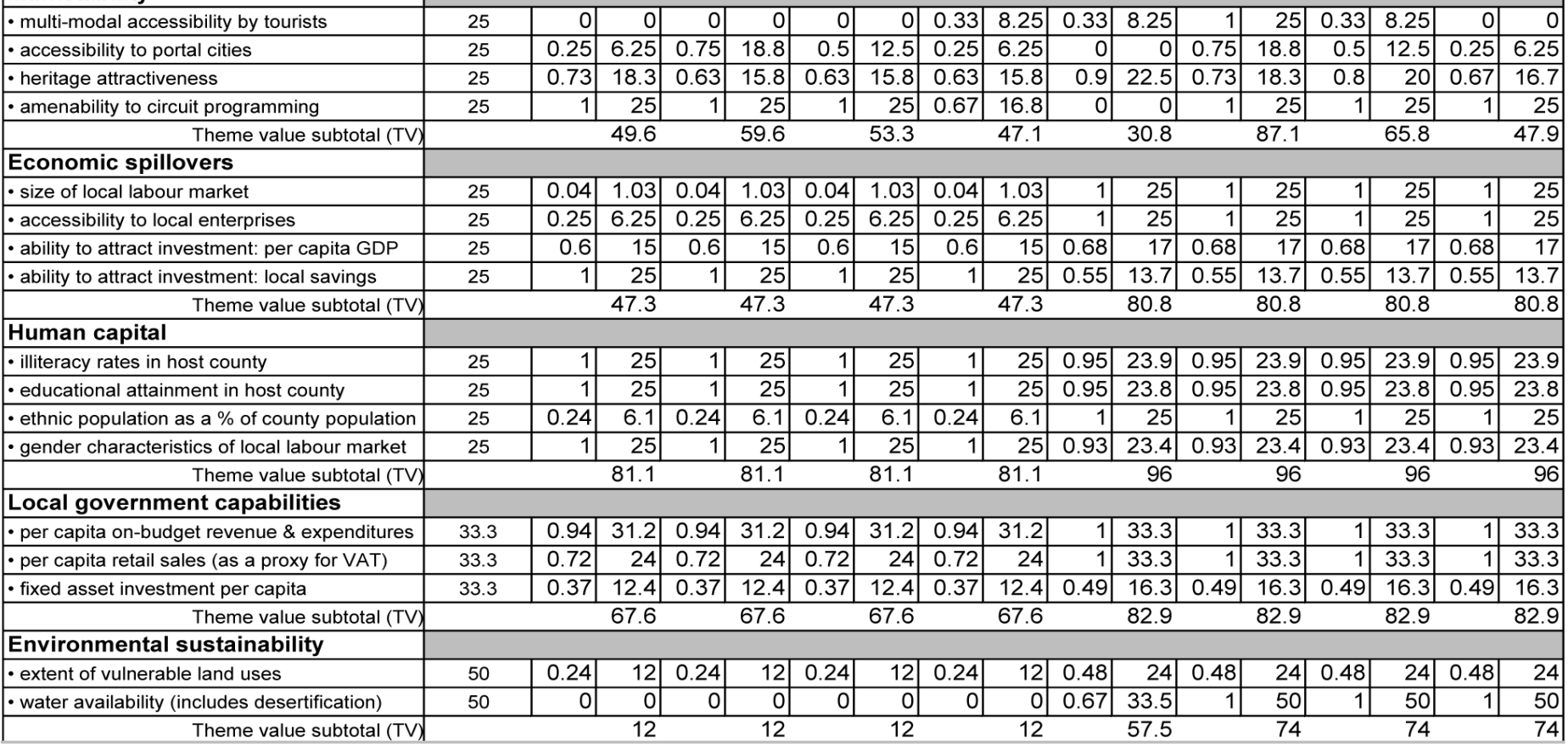

Source: Authors. 
Presentation of Overall Evaluation Results

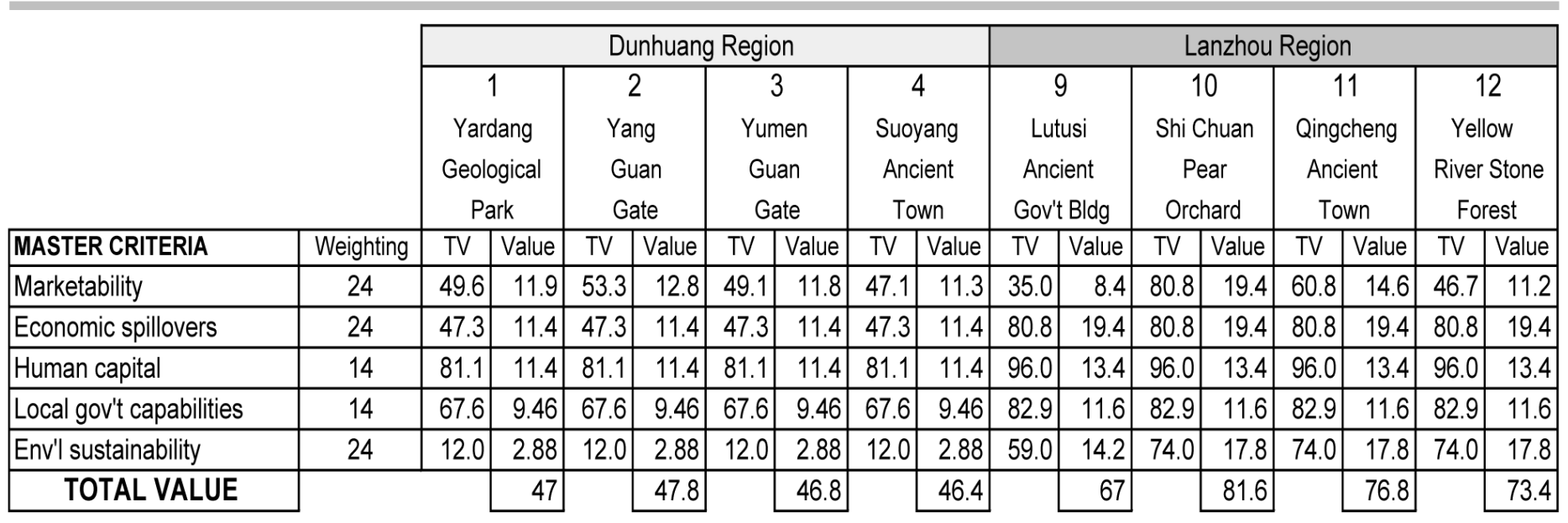

\section{Discussion of Research Results}

Since 1991, the independence of the Central Asian republics from the Soviet Union has led to an accompanying resurgence of interest in the Silk Road. Such a resurgence brings interest in Gansu Province, since it holds the outer gate to China. Within Gansu Province, the Hexi Corridor and its satellites are endowed with an unparalleled inventory of cultural and natural heritage attractions. At the same time, "the study of tourist attractions has not received the same prominence as other suppliers of tourist services" (Pearce, 1998: 1). First of all, attractions are important to tourism because they are the basic draw or tourism motive. Second, attractions offer "images and symbols" for the conservation or preservation of destinations ( $\mathrm{Hu}$ and Wall, 2005; Gartner, 1996). Third, related tourism services like transportation, lodging, and food provision are related to the attraction, and do not typically stand on their own. That constellation of factors represents the essence of investigating attractions, in China and elsewhere.

In China as in other nations, tourism growth arrives both internationally and internally as tourism plans come to fruition. More specifically, the national tourism plan of 1986-2000 helped to keep tourism on the political agenda by making it an economic pillar of growth (Zhang et. al., 2005), which means that the pent-up demand for Chinese attractions should make interior destinations more accessible over time. But, the basic conundrum remains: tourism has the capacity to impro- ve the material conditions of its destinations, which is particularly important as protected industries or trade barriers are falling under the weight of the World Trade Organization. At the same time, tourism can simultaneously be accompanied by profound environmental, economic, and cultural impacts with respect to the host communities (Harrill and Potts, 2003).

Successful tourism planning uses tourism attractions as its building blocks. "Whatever stage of tourism development has been reached, attractions can be used to reinforce, consolidate, and assist the promotion of the tourism product" (Walsh-Heron and Stevens, 1990: 12). For the Gansu Province exercise, both cultural and natural attractions were assessed according to whether they should receive public funding for subsequent development and exploitation. In this research, two evaluations were conducted regarding the attractions in order to investigate their suitability for exploitation with public funding. The first evaluation was executed according to balance (Matrix 2 where the five themes are weighted equally) and the second according to capacity to change (Matrix 3 where the five themes are weighted according to their ability to change over time).

More specifically, from Matrix 2, it is evident that the best sites for tourism investment are in the Lanzhou region. Lanzhou, the provincial capital, is on the Yellow River (a year-round source of water) and it has the province's highest transportation connectivity measures. Meanwhile, the Dunhuang region is in the middle of the desert and cannot support mass tourism. Tourism planning for the Dunhuang region needs to be segmented and focus on the luxury market only (it must also short-circuit the leakage problem involving foreign multinationals that repatriate their profits). Existing tourism resources in the Dunhuang region (e.g., the Mogao Caves UNESCO World Heritage Site) are already developing unsustainably due to the underlying water deprivation of the area. That is an important point and it warrants stressing that ecologically fragile areas cannot be targeted by tourism funding except in an extremely sensitive manner. Even ecotourism can have profound ecological implications. With the funnelled dollars arriving from luxury tourism recirculating in the local area, it may be possible to conserve heritage resources in a sustainable manner.

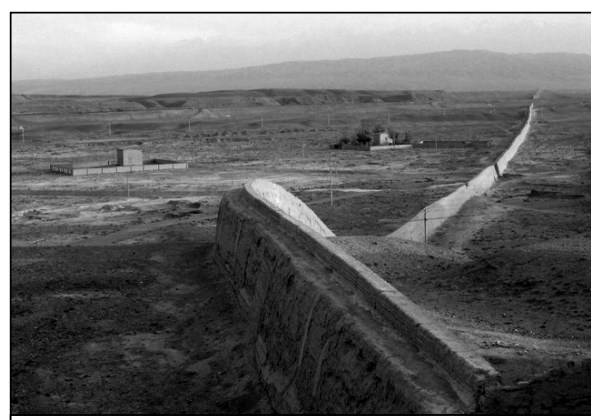

Jiayuguan Great Wall.

Photo: Jorielle pour Picassiaweb.google.com 
Matrix 3 supports the conclusions of Matrix 2 even as it corrects for the ability for a tourism venue to change over time. The best performer is the Shi Chuan Pear Orchard, which is not surprising given its advantageous geographical attributes and its nearby location to a portal city (Lanzhou). One surprising result of the evaluation process is that the Lutusi Ancient Government site did well, despite its relative geographic isolation. However, the Lutusi attraction performed consistently well across the indicators. The overall utility of the indicator selection is demonstrated by the method's efficiency and ability to be tailored to individual contexts.

The weighting scheme in Matrix 3 can be altered by the evaluators to reflect local sensitivities and local development priorities. That capacity to change weighting reflects both geography and historical development inertia. However, as stated, different local or provincial governments can develop their own weighting priorities. Of course, the evaluation process can be easily adapted to other provinces in China and other locations worldwide.

Furthermore, once the micro-level idiosyncrasies of site and situation are understood, the analyst is better able to generate overarching tourism plans and strategies that recognize macro trends. More generally, macro trends driving tourism growth include on-going improvement of global prosperity (fuelled by low interest rates), increasing levels of disposable income, safe travel conditions (for the moment), increasing availability of low-cost airlines, liberalization of travel, growing inter- and intra-regional cooperation, and better marketing (WTO, 2007). Factors that make China particularly appealing as an international destination include the weak yuan, pent-up demand for travel to China, and strong and affluent Chinese communities elsewhere in the world that are eager to visit their homeland. Simultaneously, travel throughout Asia is being facilitated by the recent emergence of Air Asia, Tiger Airways, and other low-cost airlines that are the Asian equivalents of Ryanair and EasyJet (Shameen, 2006).

\section{Conclusion}

There is little variation in the two evaluation scenarios undertaken. In this case, different weightings are not affecting the results that much as some venues are vastly more suitable for development. The interpretation of the data is twofold: focus on the Lanzhou sites and divert the Dunhuang tourism venues solely into the luxury market. The luxury market involves fewer tourists and higher on-site revenues. That tactic must be undertaken as desert tourism needs to be marketed carefully due to the overt fragility of the environment as well as the costs of shipping water to the attractions. Overall, the evaluation framework employed is expedient: it uses available data that can be hard to find in China, it is easy to calculate, and it is user-friendly to analysts and decision makers alike.

\section{Nick Novakowski is an urban geographer} and urban planner at Grenfell College, Memorial University of Newfoundland.

Rémy Tremblay is a professor at TéléUniversité (UQAM's distance learning university) and holder of the Canada Research Chair on Knowledge Cities.

Edward Leman, an architect by education, is the sole proprietor of Chreod Group Inc., a consulting firm specializing in East Asian urban and regional development processes.

\section{Note}

1 The authors would like to thank John Tinholt for generating the Gansu Province map.

\section{Bibliographie}

Baum, Tom (1994), "The Development and Implementation of National Tourism Policies ", Tourism Management, vol. 15, no. 3, p.185-192.

Gartner, William (1996), Tourism Development: Principles, Processes, and Policies, New York, Van Nostrand Reinhold.

Guangrui, Zhang (2003), "China's Tourism Since 1978: Policies, Experiences and Lessons Learned ", in Alan A. Lew, Lawrence Yu, John Ap, and Zhang Guangrui (eds.), Tourism in China, Binghamton (NY), Haworth Hospitality, p. 13-33.
Gunn, Clare (1988), Tourism Planning, New York, Taylor and Francis.

Harrill, Rich and Thomas Potts (2003), « Tourism Planning in Historic Districts: Attitudes Toward Tourism Development in Charleston ", Journal of the American Planning Association, vol. 69, no. 3, p. 233-244.

Hu, Wei and Geoffrey Wall (2005), « Environmental Management, Environmental Image and the Competitive Tourist Attraction ", Journal of Sustainable Tourism, vol. 13, no. 6, p. 617-635.

Jie, Liu (2007), "Tourism Now 6.1\% of GDP", China Daily, 9 February.

Murphy, Peter (1985), Tourism: A Community Approach, London, Routledge.

Pearce, Douglas (1989), Tourism Development, Harlow, Longman.

Pearce, Philip (1991), "Analysing Tourist Attractions ", Journal of Tourism Studies, vol. 2, no. 1, p. 46-55.

Pearce, Philip (1998), « Marketing and Management Trends in Tourist Attractions ", Asia Pacific. Journal of Tourism Research, vol. 3, no. 1, p. 1-8.

Shameen, Assif (2006), "Asia Takes Flight on LowCost Carriers ", Business Week Online, accessed 4 October, [http://www.businessweek.com/ globalbiz/content/sep2006/gb20060929_43742 1.htm?chan=top+news_top+news+index_glo bal+business].

WTO (World Tourism Organization), (2005), Asian Destinations on the Rise in World Tourism Ranking, [www.unwto.org].

WTO (World Tourism Organization), (2006), Tourism Highlights: 2006 Edition, [www.unwto.org]

WTO (World Tourism Organization), (2007), Strong Tourism Growth in 2007, [www.unwto.org].

Wagstaff, Adam and Yu Shangchao (2007), «Do Health Sector Reforms Have Their Intended Impacts? The World Bank's Health VIII Project in Gansu Province, China ", Journal of Health Economics, vol. 26, p. 505-535.

Walsh-Heron, John and Terry Stevens (1990), The Management of Visitor Attractions and Events, Englewood Cliffs (NJ), Prentice-Hall.

Wei, Yehua Dennis and Chaunglin Fang (2006), "Geographical and Structural Constraints of Regional Development in Western China: a Study of Gansu Province ", Issues \& Studies, vol. 40, no. 2, p. 131-170.

Zhang, Hanqin Qiu, Ray Pine, and Terry Lam (2005), Tourism and Hotel Development in China. From Political to Economic Success, Oxford, Haworth Hospitality Press.

Zhenggang, Guo, Liang Tiangang, and Zhang Zihe (2003), "Classification Management for Grassland in Gansu Province, China ", New Zealand Journal of Agricultural Research, vol. 46, p. 123-131. 